Foss. Rec., 23, 141-149, 2020

https://doi.org/10.5194/fr-23-141-2020

(C) Author(s) 2020. This work is distributed under

the Creative Commons Attribution 4.0 License.

\title{
A revision of Ophidiaster davidsoni de Loriol and Pellat 1874 from the Tithonian of Boulogne (France) and its transfer from the Valvatacea to the new forcipulatacean genus Psammaster gen. nov.
}

\author{
Marine Fau ${ }^{1}$, Loïc Villier ${ }^{2}$, Timothy A. M. Ewin ${ }^{3}$, and Andrew S. Gale ${ }^{3,4}$ \\ ${ }^{1}$ Department of Geosciences, University of Fribourg, Chemin du Musée 6, 1700 Fribourg, Switzerland \\ ${ }^{2}$ Centre de Recherche en Paléontologie - Paris, Sorbonne Université, 4 place Jussieu, 75005 Paris, France \\ ${ }^{3}$ Department of Earth Sciences, The Natural History Museum London, Cromwell Road, \\ South Kensington, London, UK, SW7 5BD, UK \\ ${ }^{4}$ School of Earth and Environmental Sciences, University of Portsmouth, Burnaby Building, \\ Burnaby Road, Portsmouth, PO13QL, UK
}

Correspondence: Marine Fau (marine.fau@unifr.ch)

Received: 20 April 2020 - Revised: 20 June 2020 - Accepted: 23 June 2020 - Published: 28 July 2020

\begin{abstract}
Forcipulatacea is one of the three major groups of extant sea stars (Asteroidea: Echinodermata), composed of 400 extant species, but only known from fewer than 25 fossil species. Despite unequivocal members being recognized in the early Jurassic, the evolutionary history of this group is still the subject of debate. Thus, the identification of any new fossil representatives is significant. We here reappraise Ophidiaster davidsoni de Loriol and Pellat 1874 from the Tithonian of Boulogne, France, which was assigned to another major extant group, the Valvatacea, and reassign it within a new forcipulatacean genus, Psammaster gen. nov. Psammaster davidsoni gen. nov. possess key Forcipulatacea synapomorphies including compressed ambulacrals and adambulacrals and typical organization of the body wall and arm ossicles. A phylogenetic analysis including Psammaster davidsoni gen. nov. does not place it within any existing forcipulatacean family. Instead, Psammaster davidsoni gen. nov. exhibits a mix of plesiomorphic and derived characters and is resolved as a sister clade to a large group including the Asteriidae, Stichasteridae, and Heliasteridae. Removal of this species from the Ophidiasteridae means their oldest fossil representative now dates from the Santonian, Upper Cretaceous.
\end{abstract}

\section{Introduction}

Asteroidea (starfish or sea stars) is one of the most diverse echinoderm clades with approximately 1900 extant species (Mah and Blake, 2012) and around 600 extinct species (Villier, 2006) However, the fossil record of Asteroidea is rather scarce (e.g. Gale, 2011; Mah and Blake, 2012). It is generally accepted that all modern sea stars belong to a clade, called Neoasteroidea, which originated during the Triassic (Blake, 1987; Gale, 1987, 2011), with most modern lineages appearing in the Jurassic. Jurassic fossils are therefore essential to understanding the initial diversification and evolutionary history of Asteroidea.

Forcipulatacea is one of the major clades within the Neoasteroidea, comprising about 400 extant species (Mah and Blake, 2012) and fewer than 25 extinct species. Forcipulatacea is one of the oldest clades of Neoasteroidea, with the oldest fossils known from the Hettangian (Lower Jurassic) of Switzerland and Germany (Blake, 1990). However, the diversity of forcipulatacean taxa during the Jurassic and their relationships with Triassic groups are still poorly understood. Some fossil taxa, for instance, have been attributed to extant families based on general resemblances (e.g. presence of quadriserial ambulacral pores) rather than synapomorphies (Gale, 2011).

Here we re-appraise Ophidiaster davidsoni de Loriol and Pellat, 1874, from the Tithonian of Boulogne, France, demonstrating that this taxon does not belong to the genus 
Ophidiaster L. Agassiz, 1836 (order Valvatida), as originally assigned by de Loriol and Pellat (1874). Using the phylogenetic characters and matrix from Fau and Villier (2020), we assess the phylogenetic position of Ophidiaster davidsoni within the Forcipulatacea. The combination of original characters justifies the creation of a new genus, Psammaster. The purpose of this study is to reappraise Ophidiaster davidsoni de Loriol and Pellat, 1874 and place it in a phylogenetic context.

\section{Geological settings}

The specimens (Fig. 1) were first mentioned by Wright (1870), who used the name Ophidiaster davidsoni without providing any description or diagnosis of the new taxon. The species was subsequently described by de Loriol and Pellat (1874), who further mentioned that the fossils were collected by Bouchard-Chantereaux. A few years later, Wright's fossil collection was purchased by F. H. Butler, a fossil and minerals dealer from London. The specimens were purchased by the Natural History Museum London (NHMUK) on 28 May 1887 from Francis Henry Butler. De Loriol and Pellat (1874) only illustrate one specimen, the lectotype (NHMUK PI E 53996), and therefore the second specimen purchased is considered a paralectotype (NHMUK PI E 1499).

The fossils were identified as coming from the Portlandian of Boulogne-sur-Mer (Hauts-de-France, France). De Loriol and Pellat (1874) suggested that the fossils were most likely from the "Portlandien supérieur", between the Cap d'Alpreck and Ningles, by comparing the surrounding matrix (i.e. sandstone). The upper Portlandian sandstones of this area were classified later as the "Grès des Oies Formation" (Townson and Wimbledon, 1979). The Portlandian is a local stage name formerly used in southern England and northern France and largely corresponds to the internationally recognized Tithonian stage (Ogg et al. 2012). Most of the Gres des Oies Formation falls within the upper Tithonian Kerberites kerberus zone (Townsend and Wimbledon, 1979). The Gres des Oies Formation largely comprises fine glauconitic sands containing a benthonic fauna with rare ammonites that was deposited in a shallow marine setting (Townsend and Wimbledon 1979). However, the upper part of the Gres des Oies Formation is comprised of a conglomerate overlain by hummocky cross-stratified sands (MacDonald et al. 2006, fig. 2). Thus the glauconitic sandstone matrix containing Psammaster davidsoni gen. nov. suggests that it is more likely to have originated from the lower or middle Grès des Oies Formation.

\section{Materials and methods}

\subsection{Terminology}

The anatomical descriptions follow the terminology defined in Fau and Villier $(2018,2020)$. We use the conventional terms for orientation of the specimen: abactinal (adoral) versus actinal (oral), proximal versus distal, and radial versus adradial. In the literature, the size of an individual is commonly given with the two measures " $r$ " and " $R$ ", with $r$ corresponding to the distance between the centre of the disc and the edge of the disc and $R$ corresponding to the distance between the centre of the disc and the arm tip.

\subsection{Phylogenetic analysis}

We used the matrix from Fau and Villier (2020) in order to assess the phylogenetic position of Psammaster davidsoni gen. nov. within the Forcipulatacea. The character-taxon matrix is composed of 115 morphological characters coded for 32 taxa, in particular 29 extant forcipulataceans, P. davidsoni, and two outgroups. The matrix was coded and optimized after phylogenetic analysis using MESQUITE (Maddison and Maddison, 2018). In total, 53 characters, out of 115 are scored for Psammaster davidsoni gen. nov. (see Supplement). A thorough description of all characters can be found in Fau and Villier (2020). As in the original analysis by Fau and Villier (2020), all multistate characters were left unordered and treated with equal weight. The parsimony analysis was performed with PAUP* 4.0 (Swofford, 2002).

\subsection{Systematic palaeontology}

Class Asteroidea de Blainville, 1830

Superorder Forcipulatacea Blake, 1987

Order Forcipulatida Perrier, 1884

Genus Psammaster gen. nov.

\section{Type species}

Psammaster davidsoni (de Loriol and Pellat, 1874)

\section{Derivation of name}

The prefix psammos, Ancient Greek for "sand", was chosen in reference to the sandstone formation in which the type species was found.

\section{Diagnosis}

As for type species, by monotypy.

\section{Nomenclatural acts}

This publication and its nomenclatural acts were registered at ZooBank on 29 June 2020, prior to publication. 

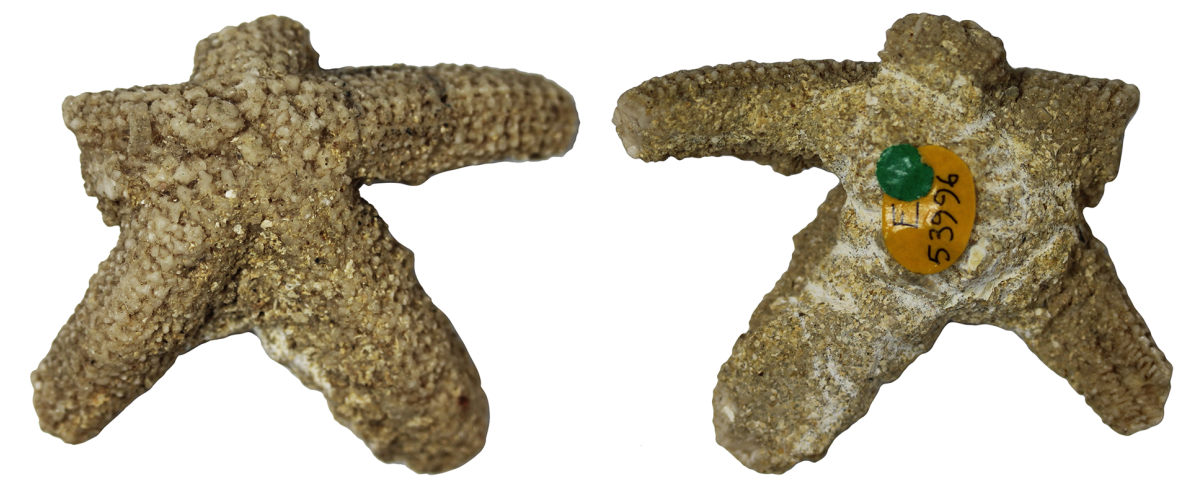

(a)

(b)

$1 \mathrm{~cm}$
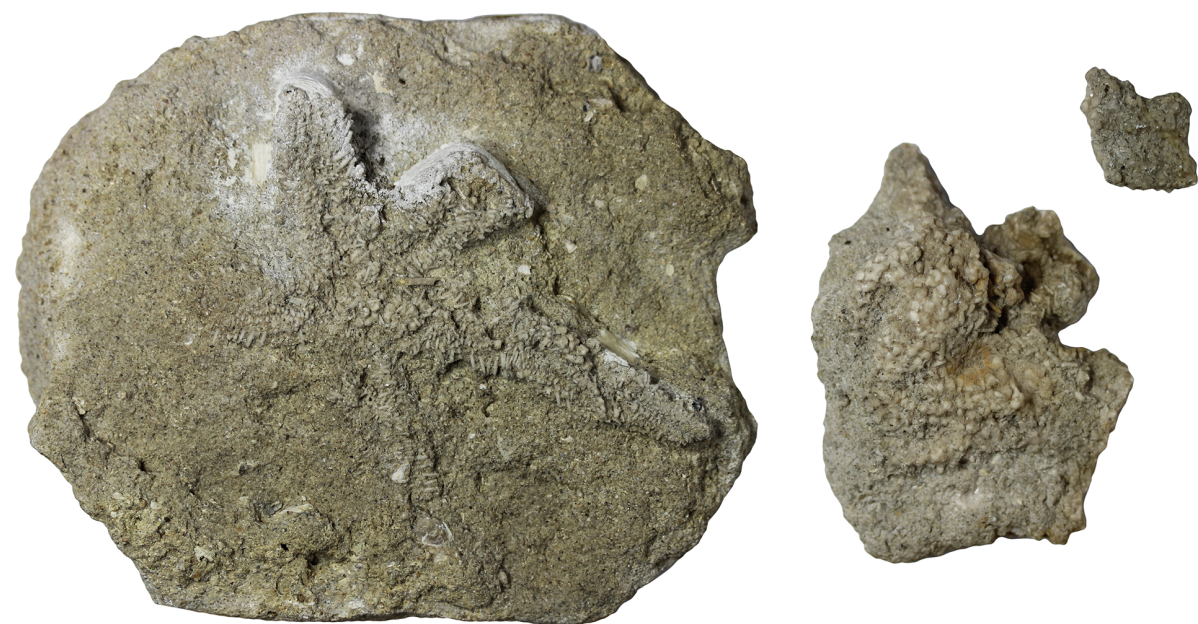

(c)

$1 \mathrm{~cm}$

(d) $1 \mathrm{~cm}$

Figure 1. The lectotype NHMUK PI E 53996, in (a) abactinal and (b) actinal views, and (c, d) the paralectotype NHMUK PI E 1499, representing at least two individuals preserved as three separate elements, (c) NHMUK PI E 1499 i, and (d) NHMUK PI E 1499 ii and iii. Scale bars: $1 \mathrm{~cm}$.

The LSID of the publication is urn:lsid:zoobank.org:pub: 6385EBA2-F315-4F69-8522-9AAA7E8EB9C4; that of the new genus is urn:lsid:zoobank.org:act: 9573D478-30534A18-8C8B-FF95A8024708.

Psammaster davidsoni (de Loriol and Pellat 1874)

1870 Ophidiaster davidsoni, Wright, p. 230, nomen nudum by lack of definition, description, or indication.

1874 Ophidiaster davidsoni de Loriol and Pellat, p. 293, pl. XXVI, figs. 13-14.

1993 Ophidiaster ? davidsoni, Lewis, p. 60.

\section{Type material}

NHMUK PI E 53996, lectotype, and NHMUK PI E 1499, paralectotype, from the Grès des Oies Formation, Tithonian of Ningle, south Boulogne-sur-Mer, Pas-de-Calais, France.

\section{Diagnosis}

Forcipulatacean asteroid with five parallel sided arms, rounded in cross section, and a small disc. Crossed shape ossicles, bearing numerous small acicular spines and a central granular spine of the same length. Arms with two rows of marginal, one carinal, one abactinal, and three rows of actinal ossicles on each side. Adambulacral rows comprised of alternating ossicles, one larger and one smaller, each bearing three to four spines.

\section{Description}

The disc and the five arms are partially preserved in the lectotype specimen (Fig. 1). The disc size is rather small $r=$ $0.8 \mathrm{~cm}$. Two arms are severed proximally. The three others are also incomplete, with the longest arm fragment reaching 
$3 \mathrm{~cm}$ in length. The abactinal surface is exposed, with most of the actinal surface being covered by sediments. The body wall ossicles (carinal, abactinal, marginal, actinal) are small and mostly cruciform in shape. One row of small, imbricate abactinals exhibit an irregular shape. The superomarginals are larger than the inferomarginals, extending into the interbrachial area up to the primary interradial plate (Fig. 2).

The primary plates of the disc are differentiated into a large, round central plate, encircled by the primary radial and interradial ossicles. The madreporite is round, as large as the central plate. The madreporite is fused with a primary interradial and likely bore spines (Fig. 2). Two primary interradials are covered by some detached spines and sediment, making it difficult to see their shape. The last two interradials are missing. The five primary radials of the disc are preserved, but only three are clearly visible, set slightly distal to the primary interradials, and are slightly bigger than the carinals. The primary radials do not seem to be directly in contact with the interradials but rather connected distally with a carinal, with two abactinals on the sides and with one or two more abactinals proximally.

The carinals are small, cruciform, and arranged in straight and regular rows (Fig. 3a-b). The external surface of the carinals is irregular, with small spines bearing bumps and often a crater in the middle of the plate for insertion of a short, rounded spine.

There is only one row of abactinals on each side of the carinal series (Fig. 3a-b). Abactinals are smaller than the carinals and are also covered with small spines. Superomarginals are identified thanks to their position and the fact that they overlap the abactinals and the inferomarginals. The continuity of the marginal series cannot be verified along the arm as no arm is preserved including the terminal ossicle.

Superomarginals are cruciform and bear many acicular spines (Fig. 3a-b). Their shape becomes more and more like a sideways " $T$ " proximally through reduction of the distal lobe. Superomarginals get larger and more conspicuous on the interradial area of the disc.

The row of plates located directly under the superomarginals is assumed to be the inferomarginals (Fig. 3a-b). The inferomarginals are small-sized ossicles with a cruciform to triangular shape and a reduced abactinal lobe. Carinals, abactinals, and marginals seem to bear one big central spine, while the rest of the plate is covered with many smaller and thinner spines. Only the spine base of the central spines remains, but many of the small and thin spines are visibly strewn between the plates.

At least three rows of actinals are present (Fig. 3a, c), but some actinals might be missing because of the nonpreservation of the actinal part of the specimen. The actinals are small, are cruciform to round, have at least one big central spine per actinal, and are likely to be covered in smaller spines as well.

Ambulacrals are visible on two parts of one of the arms of the lectotype (Fig. $3 \mathrm{~b}-\mathrm{c}$ ). The ambulacral heads are visible between the abactinal ossicles and in the ambulacral groove. The ambulacral groove is only partially visible for around $5 \mathrm{~mm}$ at the distalmost part of the arm. The ambulacrals appear compressed, but it is impossible to count, with certainty, the number of tube feet rows. The crest does not bend proximally. In total, 19 adambulacrals can be observed, but most of the spines have been removed. Some adambulacral spines are found inside the ambulacral groove. There were probably between three and four spines per adambulacral. The adambulacral spines are long, are cylindrical, and have a blunt point. The adambulacrals are compressed, short, and wide. Three adambulacrals are significantly wider than their direct neighbours, like some carinate adambulacrals. The alternation of two differentiated size of adambulacral ossicles is likely.

Due to the preservation of the specimen, it is difficult to recognize pedicellariae. However, a crossed pedicellariae is visible on one arm. It is possible that crossed pedicellariae were widespread throughout the body, but were not preserved.

The paralectotype NHMUK PI E 1499 is composed of three distinct elements, two partial discs and an isolated partial arm, from at least two different individuals (Fig. 1c-d). They represent bigger individuals than the lectotype. The larger individual (NHMUK PI E 1499 i) allows partial description of the actinal surface. It is poorly preserved and the surface is largely obscured by sediment and disorganized spines with the most visible parts being the adambulacral spines and the actinal edge of the adambulacrals. Four arms are broken, of which only one is complete to the terminal ossicles and measures approximately $55 \mathrm{~mm}$. It is difficult to measure this individual due to the poor preservation of its disc, but we estimate it to be between $r=9$ and $r=13 \mathrm{~mm}$.

The medium-sized individual (NHMUK PI E 1499 ii) shows the body wall skeleton. Sediments cover the interradial region, making recognition of ossicle homology difficult.

The third piece (NHMUK PI E 1499 iii) shows mostly spines, but no particular structure of the skeleton. It probably represents an arm fragment.

\section{Discussion}

\subsection{Alpha taxonomy}

The presence of compressed ambulacrals and adambulacrals (Fig. 3), as well as the general organization of the wall skeleton following the Forcipulatid plating rule (FPR) (as defined by Gale, 2011), leaves no doubt that Psammaster davidsoni gen. nov. belongs to the Forcipulatacea. This is contrary to its previous attribution to the Valvatacea as implied by its original allocation to the extant genus Ophidiaster. Species of the genus Ophidiaster and other members of the family Ophidiasteridae are characterized, amongst other features, by five cylindrical arms covered in granules, narrow am- 

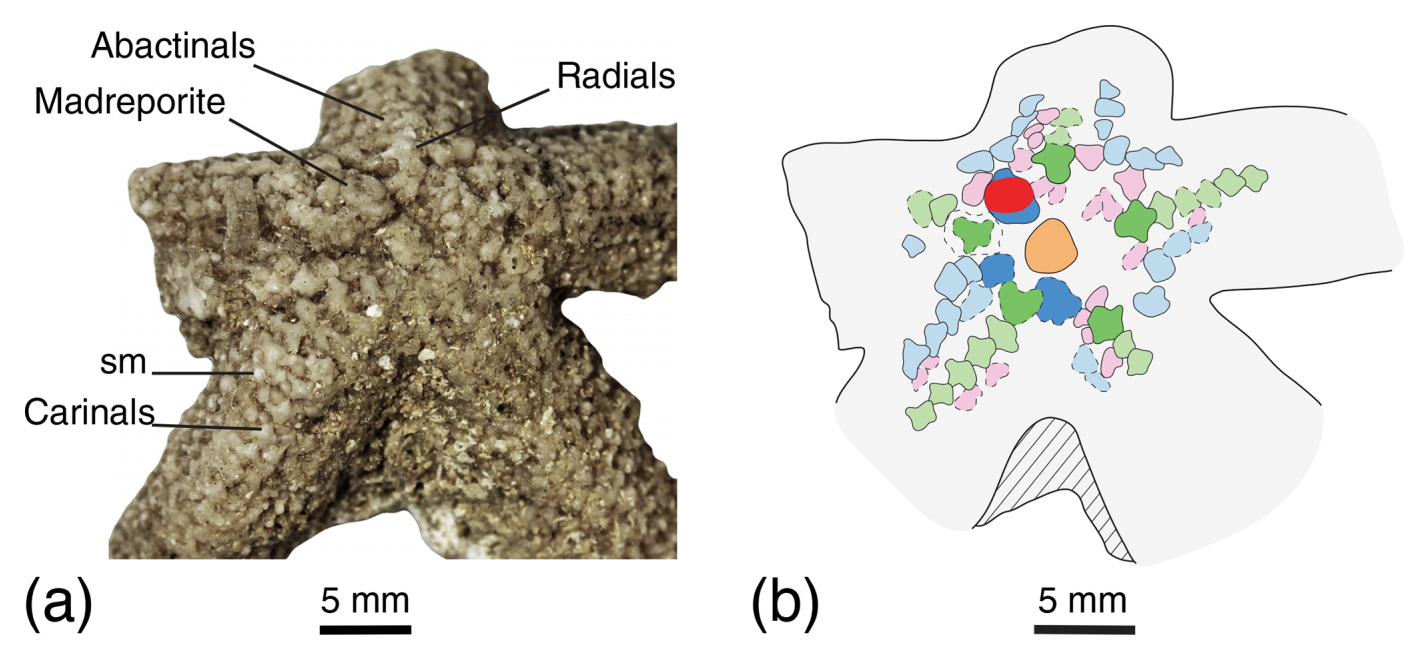

Figure 2. Disc of the lectotype NHMUK PI E 53996, (a) photography and (b) interpretation drawing. Dashed lines indicate uncertain contour of the ossicles. Coloured areas indicate ossicle homology. Orange: the central; red: the madreporite; light green: carinals; dark green: primary radials; light blue: superomarginals; dark blue: primary interradials; pink: abactinals. Scale bars: $5 \mathrm{~mm}$.

bulacral grooves, and two rows of differentiated spines on the adambulacrals (Fisher, 1906; Koehler, 1921). Psammaster davidsoni, on the contrary, shows five tapering arms and no sign of any surface granules, and its ambulacral groove is open and lacks differentiation into adambulacral spine sets.

Psammaster davidsoni differs from the Jurassic species Terminaster cancriformis (Quenstedt, 1876) by possessing compressed ambulacrals and adambulacrals and the presence of three rows of actinals (only one in T. cancriformis). Protothyraster priscus (de Loriol, 1874 ) from the Hauterivian of Switzerland was initially described as an Echinasteridae but subsequently revised by Hess (1970) and attributed to the Forcipulatacea by Gale (2011). Protothyraster priscus differs from $P$. davidsoni by lacking compressed ambulacrals and adambulacrals and the presence of only a single row of actinals, as in T. cancriformis. Alkaidia sumralli Blake and Reid, 1998 from the Albian of Texas (USA) was originally described as a Paleobenthopectinidae; however, Ewin and Gale (2020) recently described Alkaidia megaungula from the Barremian of Morocco and transferred both species of Alkaidia to the Forcipulatacea due, amongst other features, to the presence of forcipulate pedicellariae and the organization of the wall skeleton following the FPR. Psammaster davidsoni differs from both A. sumralli and A. megaungula by the absence of prominent pustules on the marginals and its compressed adambulacrals and ambulacrals.

"Asterias" gaveyi Forbes, 1850 from the Pliensbachian of England is a Forcipulatida known only from its actinal side, which makes comparison with $P$. davidsoni difficult. However, the highly compressed ambulacrals and adambulacrals of "A." gaveyi, which clearly shows four rows of tube feet and the presence of four to five spines per adambulacral (Wright, 1863, Hess, 1972), are enough to distinguish it from P. davidsoni.
"Compsaster" spiniger (Wright, 1880) is another Jurassic asteriid, from the Bathonian of England. It is known only from its actinal side. "Compsaster" spiniger presents some similarities with $P$. davidsoni, as both possess compressed adambulacrals of slightly alternate size, each bearing three to four spines, but " $C$." spiniger also possesses long and thick spines, as well as many large-sized, crossed, and straight pedicellariae. Long thick spines are absent in P. davidsoni.

In the literature, the oldest taxa attributed to the Asteriidae are Germanasterias amplipapularia Blake, 1990 and Hystrixasterias hettangiurnus Blake, 1990 from the Hettangian of southern Germany. Germanasterias amplipapularia exhibits an overall similar organization of the wall skeleton to $P$. davidsoni, but its ossicles are cruciform to digitated and the skeleton is reticulate, whereas $P$. davidsoni has more bulky cruciform ossicles and a more compact organization of the skeleton. The ambulacral and adambulacrals of G. amplipapularia are also more compressed (Blake, 1990). Hystrixasterias hettangiurnus has ossicles that are similar to those of $P$. davidsoni, but $H$. hettangiurnus possesses up to three rows of abactinals (Blake, 1990) where $P$. davidsoni only has one. Three other Mesozoic taxa are attributed to the Asteriidae: Savignaster villieri Gale, 2011 from the Oxfordian of France, Polarasterias janusensis Rousseau and Gale, 2018 (in Rousseau et al., 2018) from the Tithonian of Norway, and Cretasterias reticulatus Gale and Villier, 2013 from the Maastrichtian of Morocco. Those three species exhibit a reticulate skeleton with cruciform ossicles possessing four distinct processes and therefore cannot be confused with $P$. davidsoni.

Afraster scalariformis Blake et al., 1996, a pedicellasterid from the Coniacian of Angola, differs from P. davidsoni by having differentiated abactinals in addition to its reticulate skeleton. Indeed $P$. davidsoni only has one row of uniform 


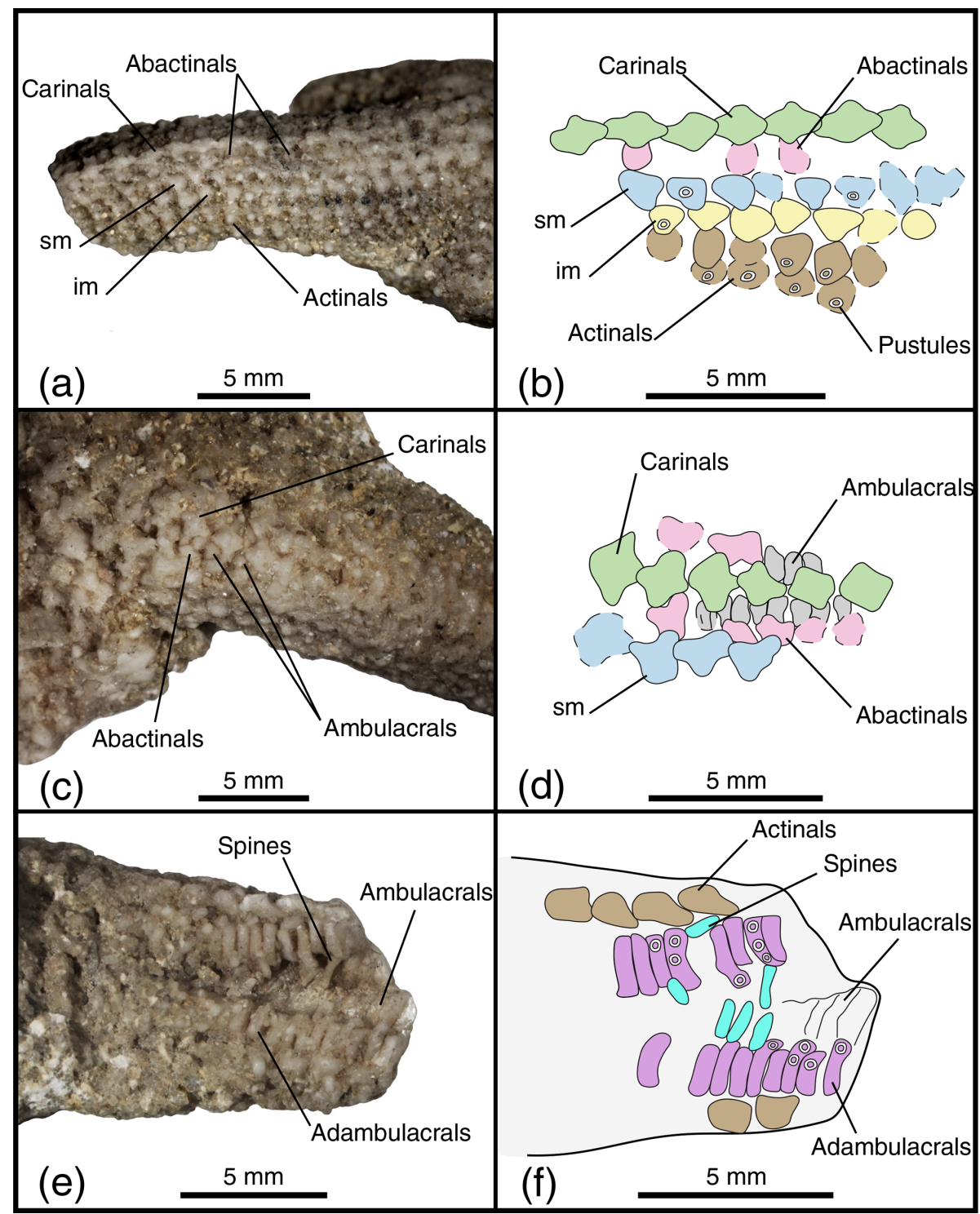

Figure 3. Arrangement of the body wall and arm ossicles of Psammaster davidsoni (a, b, c, d) and the ambulacral groove (e, f). Photographs $(\mathbf{a}, \mathbf{c}, \mathbf{e})$ and interpretation drawings $(\mathbf{b}, \mathbf{d}, \mathbf{f})$ of the lectotype NHMUK PI E 53996. Dashed lines indicate uncertain contour of the ossicles. Coloured areas indicate ossicle homology. In orange: the central ossicle; in red: the madreporite; in green: carinals; in pink: abactinals; in blue: superomarginals; in yellow: inferomarginals; in brown: actinals; in grey: ambulacrals; in purple: adambulacrals; in teal: adambulacrals spines. Scale bars: $5 \mathrm{~mm}$.

abactinals, whereas $A$. scalariformis is described as presenting abactinals with two distinct morphologies.

Another Cretaceous forcipulatacean taxon, Pegaster stichos Blake and Peterson, 1993 from the Campanian of California (USA), shows many similarities with $P$. davidsoni. Pegaster stichos, just as $P$. davidsoni, possess compressed ambulacrals, but quadriserial tube feet cannot be assessed with certainty. The adambulacrals are compressed and alternate in size, each bearing three to four spines, and they possess two rows of marginals and one row of abactinals on either side of the carinal row. Pegaster stichos further- more show four rows of actinals, whereas $P$. davidsoni possess only three. As the specimen of $P$. stichos is larger than P. davidsoni, the morphological differences could be due to size, as larger specimens tend to have more rows of ossicles. The main difference between these two species is the shape of the ossicles. P. stichos possess ossicles with a peg-like surface and show no sign of spine insertion at all, whereas the best-preserved ossicles of $P$. davidsoni clearly have a central pustule and insertions for smaller, cylindrical spines. No ossicles of $P$. davidsoni show any peg-like structure. 


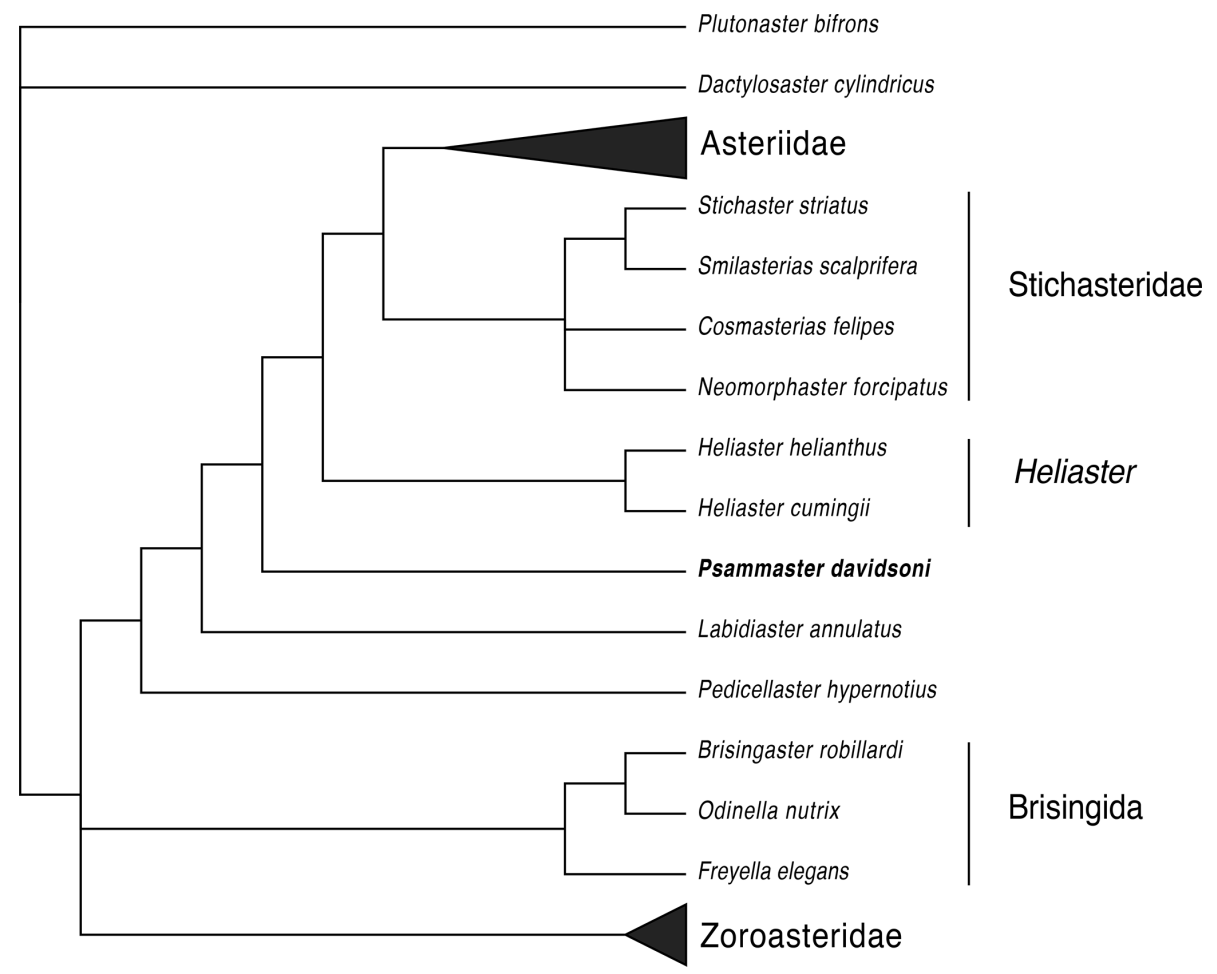

Figure 4. Strict consensus of the 61 most parsimonious trees found. Character matrix from Fau and Villier (2020) is available in the Supplement. Asteriidae $(n=12$ taxa) and Zoroasteridae $(n=4$ taxa) were grouped for clarity.

The most similar taxa to $P$. davidsoni, in terms of morphology, are the Jurassic Argoviaster occultus Hess, 1972 and Dermaster boehmi de Loriol, 1899 from the Bajocian of Switzerland. Hess (1972) proposed placing A. occultus within the Neomorphasterinae and created the Dermasterinae for $D$. boehmi, both subfamilies belonging to the family Asteriidae. Recent taxonomic revision synonymized Neomorphasterinae with Stichasterinae, changed the taxon rank of Stichasterinae to family level, and classified the family as a sister group to the Asteriidae (Fau and Villier, 2020). Argoviaster occultus is described with a compact skeleton, four rows of tube feet, and straight pedicellariae (Hess, 1972). However, A. occultus differs from P. davidsoni in many aspects: (i) carinals, abactinals, and marginals of A. occultus tend to be triangular in shape, with the distal lobe being reduced, which is not the case in $P$. davidsoni; (ii) the largest specimens of $A$. occultus possibly show more than one row of abactinals, at least proximally; and (iii) adambulacrals of A. occultus are regular in size. Dermaster boehmi, similarly to $P$. davidsoni, has cruciform carinals, a single row of abactinals, and two rows of marginals, with all of these plates being covered with small thin spines with one bigger robust central spine on each plate and three to four spines on the adambulacrals. However, D. boehmi possesses a more reticulate skeleton than P. davidsoni. The cruciform shape of the carinals and superomarginals, especially proximally, is better defined in D. boehmi. Primary radials of D. boehmi have five lobes, whereas primary radials of $P$. davidsoni only have four lobes. On the disc, the madreporite of $P$. davidsoni is relatively large and occupies a large part of the disc, whereas the madreporite of Dermaster boehmi is comparatively small and inconspicuous.

\subsection{Phylogenetic analysis}

The heuristic search produced 61 most parsimonious trees (tree length: 358 steps; consistency index: 0.3911; homoplasy index: 0.6089). The strict consensus of these 61 most parsimonious trees (Fig. 4) recovers the relationships among the main clades as in Fau and Villier (2020). Only the topology inside the Asteriidae shows some variation, but this is beyond the scope of this study. Psammaster davidsoni gen. nov. appears as the sister taxon to the clade Heliaster + Stichasteridae + Asteriidae and does not fit into any of the extant clades or families recovered by this analysis (Fig. 4). This phylogenetic position is in accordance with our morphological observations. Psammaster davidsoni exhibits a mix of plesiomorphic and derived characters. Noticeable plesiomorphic characters are the not tilted crest of the ambulacrals (character 30 ), the presence of secondary spines (characters 61-69, 77,92 ), and the unique row of undifferentiated abactinals (character 78 and characters 79-81, also shared with the Stichasteridae). Synapomorphies of the clade Psammaster 
davidsoni + Heliaster + Stichasteridae + Asteriidae are the absence of wings on the ambulacrals (character 34), the symmetrical heads of the ambulacrals (character 31), and the high level of compression of the adambulacrals (character 41). Psammaster davidsoni also exhibits convergent morphology of its spines with the Stichasteridae and the clade Heliaster, as all of these taxa have rather stout and short primary spines on the marginals, abactinals, and carinals. However, P. davidsoni is unique in having two different types of spines, assumed to be homologous with the primary and secondary spines of extant Zoroasteridae. The presence of secondary spines would be a plesiomorphic condition within the Forcipulatacea.

\subsection{Fossil record of the Ophidiasteridae}

The removal of $P$. davidsoni from the family Ophidiasteridae has an important impact on the fossil record of this family. The extant Ophidiasteridae is very diverse, with more than 100 species described (Mah and Blake, 2012). However the fossil record of this family is rather poor and only represented by four Mesozoic species: Denebia americana (Adkins, 1928) and Altaria wintoni (Adkins, 1928) from the Albian of Texas (Blake and Reid, 1998) and Sladenia fourtaui de Loriol 1904 and Chariaster elegans de Loriol 1909 from the Santonian of Abou-Roach, Egypt (de Loriol 1909). Blake and Reid (1998) compared Denebia americana and Altaria wintoni to the Ferdina group, sensu Marsh and Campbell (1991). However, Mah and Foltz (2011) provided evidence for the polyphyly of the traditional Ophidasteridae. They suggest that the Ferdina group and several other genera instead belong to the Goniasteridae. This implies that both Denebia americana and Altaria wintoni, because of their affinity with the Ferdina group (Blake and Reid, 1998), are in fact goniasterids. Spencer (1907) described the specimen BNHM E 5055 from the Lower Chalk of England as an Ophidiasterid (Linckia sp.). A rapid examination of the specimen is sufficient to realize that the spinose plates of the body wall are incompatible with an assignment to the Ophidiasteridae. Psammaster davidsoni was the earliest occurrence of the family Ophidiasteridae, and its removal delays the appearance of this family from the Late Jurassic (Tithonian) to the Upper Cretaceous (Santonian) at best, pending revision of the Egyptian forms.

Data availability. All material examined in this study is accessible in the listed institutions, and all data are described in the text and figures. The character-taxa matrix is from Fau and Villier (2020), to which we added $P$. davidsoni. List and character description is available in Appendix 1 of Fau and Villier (2020). The character matrix including $P$. davidsoni is available in the Supplement.

Supplement. The supplement related to this article is available online at: https://doi.org/10.5194/fr-23-141-2020-supplement.
Author contributions. MF illustrated and described the material, performed the phylogenetic analysis, and wrote the primary draft of the manuscript. MF, LV, and TAME contributed to morphological analysis and interpretation of the material. LV, TAME, and ASG worked on the manuscript and contributed to the editing. All authors reviewed the final version of the manuscript and approved it.

Competing interests. The authors declare that they have no conflict of interest.

Acknowledgements. We are thankful to Walter Joyce (University of Fribourg) for his support and for reading an earlier draft of this paper. We thank Chris Mah and the anonymous reviewer for their comments that helped improve the manuscript.

Financial support. This work was supported by a grant from Synthesys (GB-TAF-6581) to Marine Fau for visiting the Natural History Museum (London) in June 2017 and by funds from the Department of Geosciences of the University of Fribourg.

Review statement. This paper was edited by Florian Witzmann and reviewed by Chris Mah and one anonymous referee.

\section{References}

Adkins, W. S.: Handbook of Cretaceous fossils, University Texas Bull., 2838, 1-385, 1928.

Agassiz, L.: Prodrome d'une monographie des Radiaires ou Echinodermes, Mém. Soc. Sci. Nat. Neuchatel, 1, 168-199, 1836.

Blake, D. B.: A classification and phylogeny of post-Palaeozoic sea stars (Asteroidea: Echinodermata), J. Nat. Hist., 21, 481-528, 1987.

Blake, D. B.: Hettangian Asteriidae (Echinodermata: Asteroidea) from southern Germany: taxonomy, phylogeny and life habits, Paläont. Z., 64, 103-123, 1990.

Blake, D. B. and Peterson, D. O.: An unusual new asteriid (Echinodermata: Asteroidea) from the Cretaceous of California, J. Paleontol., 67, 586-589, 1993.

Blake, D. B. and Reid, R.: Some Albian (Cretaceous) asteroids (Echinodermata) from Texas and their paleobiological implications, J. Paleontol., 72, 512-532, 1998.

Blake, D. B., Breton, G., and Gofas, S.: A new genus and species of Asteriidae (Asteroidea; Echinodermata) from the Upper Cretaceous (Coniacian) of Angola, Africa, Paläont. Z., 70, 181-187, 1996.

de Blainville, H. M.: Zoophytes, in: Dictionnaire des sciences naturelles, 6, edited by: Levrault, F. G., Strasbourg, Paris, 1-546, 1830.

de Loriol, P.: Description de quelques astérides du terrain Néocomien des environs de Neuchâtel, Mem. Soc. Sci. Nat. Neuchatel, 4, 3-19, 1874.

de Loriol, P.: Über einen neuen fossilen Seestern, Mitt. Bad. Geol. Landesanst., 4, 1-4, 1899. 
de Loriol, P.: Notes pour servir à l'étude des échinodermes, Georg \& Co, Bâle, Genève, Berlin, 2, 1-68, 1904.

de Loriol, P.: Note sur quelques stellérides du Santonien d'AbouRoach, Bull. Inst. Egypte, 5, 169-184, 1909.

de Loriol, P. and Pellat, E.: Monographie paléontologique des étages supérieurs de la formation jurassique des environs de Boulogne-sur-Mer, Mem. Soc. Phys. Hist. Nat. Geneve, 24, 1292, 1874.

Ewin, T. A. M. and Gale, A. S.: Asteroids (Echinodermata) from the Barremian (Lower Cretaceous) of the Agadir Basin, west Morocco, J. Paleontol., in press, https://doi.org/10.1017/jpa.2020.20, 2020.

Fau, M. and Villier, L.: Post-metamorphic ontogeny of Zoroaster fulgens Thomson, 1873 (Asteroidea, Forcipulatacea), J. Anat., 233, 644-665, https://doi.org/10.1111/joa.12881, 2018.

Fau, M. and Villier, L.: Comparative anatomy and phylogeny of the Forcipulatacea (Echinodermata: Asteroidea): insights from ossicle morphology, Zool. J. Linnean Soc., 189, 921-952, 2020.

Fisher, W. K.: The starfishes of the Hawaiian Islands, Fish. Bull., 23, 987-1130, 1906.

Forbes, E.: Figures and descriptions illustrative of British organic remains, Memoirs of the Geological Survey of the United Kingdom, decade 3, plate 2, 65, 1850.

Gale, A. S.: Phylogeny and classification of the Asteroidea (Echinodermata), Zool. J. Linnean Soc., 89, 107-132, 1987.

Gale, A. S.: The phylogeny of post-Palaeozoic Asteroidea (Neoasteroidea, Echinodermata), Spec. Pap. Palaeontol., 85, 1-112, 2011.

Gale, A. and Villier, L.: Mass mortality of an asteriid starfish (Forcipulatida, Asteroidea, Echinodermata) from the late Maastrichtian (Late Cretaceous) of Morocco, Palaeontology, 56, 577588, 2013.

Hess, H.: Schlangensterne und seesterne aus dem oberen Hauterivien "Pierre jaune" von St-Blaise bei Neuchâtel, Eclogae Geol. Helv., 63, 1069-1091, 1970.

Hess, H.: Eine Echinodermen-Fauna aus dem mittleren Dogger des Aargauer Juras, Schweiz. Palaeontol. Abh., 92, 1-87, 1972.

Koehler, R.: Faune de France, 1 Echinodermes, Fédération française des Sociétés de Sciences naturelles (Éd.), Paris, France, 1921.

Lewis, D. N.: Catalogue of the type and figured specimens of fossil Asteroidea and Ophiuroidea in The Natural History Museum, Bull. Nat. Hist. Mus., 49, 47-80, 1993.

MacDonald, I., Irvine, G. J., de Vos, E., Gale, A. S., and Reimold, W. E.: Geochemical search for impact signatures in possible impact-generated units associated with the Jurassic-Cretaceous boundary in southern England and northern France, in: Biological processes associated with impact events, edited by: Cockerell, C., Koeberl C., and Gilmour, R., Springer, Berlin, Heidelberg, 257-286, 2006.
Maddison, W. P. and Maddison, D. R.: Mesquite: a modular system for evolutionary analysis, Version 3.51, available at: http://www. mesquiteproject.org (last access: 22 July 2020), 2018.

Mah, C. and Foltz, D.: Molecular phylogeny of the Valvatacea (Asteroidea: Echinodermata), Zool. J. Linnean Soc., 161, 769-788, https://doi.org/10.1111/j.1096-3642.2010.00659.x, 2011.

Mah, C. L. and Blake, D. B.: Global diversity and phylogeny of the Asteroidea (Echinodermata), PLoS ONE, 7, e35644, https://doi.org/10.1371/journal.pone.0035644, 2012.

Marsh, L. M. and Campbell, A. C.: A new species of Ferdina (Echinodermata: Asteroidea) from the Sultanate of Oman with discussion of the relationships of the genus within the family Ophidiasteridae, Bull. Br. Mus. Nat. Hist. Zool., 57, 213-219, 1991.

Ogg, J. G. and Hinnov, L. A.: Jurassic. Chapter 26, in: The Geologic Time Scale 2012, edited by: Gradstein, F. M., Ogg, J. G., Schmitz, M. D., and Ogg, G. M., Elsevier, 731-791, 2012.

Perrier, E.: Mémoire sur les étoiles de mer recueillies dans la mer des Antilles et le golfe du Mexique: durant les expéditions de dragage faites sous la direction de M. Alexandre Agassiz, Archive du Muséum national d'histoire naturelle, Paris, 6, 127276, 1884.

Quenstedt, F. A.: Petrefaktenkunde Deutschlands, 1 abt., Echinodermen (Asteriden und Encriniden), edited by: Fues, L. F., Leipzig, 742 pp., 1876.

Rousseau, J., Gale, A. S., and Thuy, B.: New articulated asteroids (Echinodermata, Asteroidea) and ophiuroids (Echinodermata, Ophiuroidea) from the Late Jurassic (Volgian?/?Tithonian) of central Spitsbergen, Eur. J. Taxon., 411, 1-26, 2018.

Spencer, W. K.: A Monograph of the British Fossil Echinodermata from the Cretaceous formations, Vol. 2: The Asteroidea and Ophiuroidea, Palaeontogr. Soc. Monogr., 2, 91-132, 1907.

Swofford, D. L.: PAUP*: Phylogenetic analysis using parsimony (* and other methods), Version 4.0, Sinauer Associates, Sunderland, Massachusetts, 2002.

Townson, W. G. and Wimbledon, W. A.: The Portlandian strata of the Bas Boulonnais, France, Proc. Geol. Assoc., 90, 81-91, https://doi.org/10.1016/S0016-7878(79)80035-8, 1979.

Villier, L.: Asterozoans, Paleobiology database online systematics archive, available at: http://paleodb.org/ (last access: 26 June 2020), 2006.

Wright, T.: Monograph on the British Fossil Echinodermata of the Oolitic Formations, Volume II. - The Asteroidea and Ophiuroidea, Palaeontogr. Soc. Monogr., 1861, 1-130, 1863.

Wright, T.: On the correlation of the Jurassic rocks in the department of the Côte-d'Or, France, with the Oolitic Formations in the counties of Gloucester and Wiltshire, Proc. Cotteswold Nat. Fld. Club, 5, 143-238, 1870. 